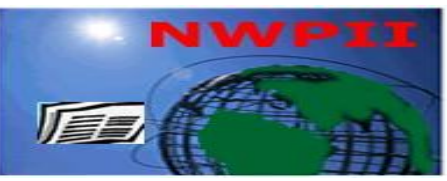

American Journal of Biomedical Sciences

ISSN: 1937-9080

nwpii.com/ajbms

\title{
In Vivo Antidiarrheal and Cytotoxic Potential of Different Fractions of Pandanus Foetidus Leaves
}

\author{
Abu Mohammed Taufiqul Islam ${ }^{1}$, Muhammad Erfan Uddin ${ }^{2}$, Md. Asharf Uddin Chowdhury ${ }^{2}$, \\ Md. Mominur Rahman ${ }^{2}$, Md. Razibul Habib ${ }^{3}$, Md. Atiar Rahman ${ }^{4 *}$
}

\author{
${ }^{1}$ Department of Systems Immunology, College of Biomedical Science, Kangwon National \\ University, Chuncheon, Gangwondo, Korea 200-701. \\ ${ }^{2}$ Department of Pharmacy, International Islamic University Chittagong, Bangladesh. \\ ${ }^{3}$ Superintendent of Drugs, Directorate General of Drug Administration, Bangladesh. \\ ${ }^{4}$ Department of Biochemistry and Molecular Biology, University of Chittagong. \\ *Corresponding author: \\ M. Atiar Rahman PhD, \\ Assistant Professor, Department of Biochemistry and Molecular Biology \\ University of Chittagong \\ Chittagong-4331, Bangladesh \\ Tel:+88-31-2606001-10, Extn-4334 \\ Fax:+88-31-726310 \\ E-mail: atiarh@yahoo.com
}

Received: 22 April 2013; | Revised: 20 July 2013; | Accepted: 31 July 2013

\begin{abstract}
This study investigated the antidiarrheal and cytotoxic effects of methanol, petroleum ether, chloroform and aqueous fractions of Pandanus foetidus leaf extract. Antidiarrheal effect was measured in castor oil induced- diarrhea, -enteropooling and -gastrointestinal motility (GI) test models in albino mice. Cytotoxicity was investigated in brine shrimp lethality bioassay. All data were analyzed by the software, statistical package for social science (SPSS), Version 18.0. The extracts $(200 \mathrm{mg} / \mathrm{kg})$ showed a remarkable antidiarrheal activity by reducing the number of defecation and maintaining the consistency of feces. The petroleum ether, chloroform and aqueous fraction of the extract significantly $(\mathrm{p}<0.05)$ inhibited the diarrheal incidence at the dose of $200 \mathrm{mg} / \mathrm{kg}$. Castor oil induced enteropooling and fluid accumulation was significantly reduced by methanol and chloroform fraction, whereas gastrointestinal motility was shrunk by the aqueous fraction only. Loperamide was used as a reference drug in the above mentioned models. In cytotoxicity test, the lowest $\mathrm{LC}_{50}$ was found to be $106.97 \mu \mathrm{g} / \mathrm{ml}$ by the chloroform fraction of the extract. The results demonstrated that Pandanus foetidus extract could be used as pharmaceutical preparation of antidiarrheal and cytotoxic agent obtained from appropriate solvent system.
\end{abstract}

Keywords: Antidiarrheal activity; castor oil; enteropooling; intestinal transit; cytotoxicity; Pandanus foetidus. 


\section{Introduction}

Pandanus foetidus Roxb. (Pandanaceae), locally known as kewa kata, Keora, Keurikanta or Kewakanta, a common hedge-plant with no proper stem, grows throughout Bangladesh, mainly in the coastal region of the mangrove forest, Sundarban [1] and Chittagong. Leaves of this plant are used in leprosy, small pox, syphilis, scabies and heart and brain diseases [2, 3]. Leaves and spadix are also used in diabetes [3]. Methanol extract of $P$. fotetidus leaves was found to show potential depressant effect on the central nervous system by interfering the cortical function in mice. Essential oil of $P$. foetidus is also used as perfumery as well as medicinal sources [4]. As a part of our ongoing investigation on medicinal plants of Bangladesh, we reported here the antidiarrheal and cytotoxic activities of $P$. foetidus leaf extract.

\section{Materials and methods}

\subsection{Chemical and reagents}

Petroleum ether (99\%), chloroform (99.5\%) and methanol (99.5\%) were purchased from Sigma-Aldrich (India). Loperamide (Square Pharmaceuticals Ltd., Bangladesh), castor oil (WELL's Heath Care, Spain), normal saline solution $(0.9 \% \mathrm{NaCl})$ and charcoal meal $(10 \%$ activated charcoal in 5\% gum acacia) were used in animal model study.

\subsection{Plant material}

Pandanus foetidus leaves were collected from the local forest of Chittagong district, Bangladesh in the months of August-September, 2012 and were authenticated by Dr. Sheikh Bokhtear Uddin, Taxonomist and Associate Professor, Department of Botany, University of Chittagong, Chittagong-4331, Bangladesh. A voucher specimen (K 4031) of the plant sample has been preserved in Bangladesh National Herbarium for future reference.

\subsection{Preparation of crude extract}

The collected plant samples were washed thoroughly with water, chopped and air dried for a week at $35-40^{\circ} \mathrm{C}$ to pulverize by electric grinder (Miyako 3 in one grinder, China). The obtained powder $(500 \mathrm{~g})$ was soaked into methanol at room temperature $\left(25 \pm 2{ }^{\circ} \mathrm{C}\right)$ for 10 days with a two days interval. The extracts were filtered (Whatman No. 1) and concentrated to dryness in vacuo using rotary evaporator (RE200, Bibby Sterling, UK) under reduced pressure below $50^{\circ} \mathrm{C}$. The powdered extract $23 \mathrm{~g}$, blackish-green, yield $4.6 \% \mathrm{w} / \mathrm{w}$ ) was preserved at $4^{\circ} \mathrm{C}$ for further use.

\subsection{Fractionation of crude extract}

Crude extract was further fractionated by petroleum ether, chloroform, methanol and water using separation funnel. The fractions were designated as petroleum ether fraction (PFPE), chloroform fraction $(\mathrm{PFCH})$, methanol fraction (PFME) and aqueous fraction (PFAQ) for further analysis.

\subsection{Experimental animals}

Six-week-old Swiss Albino mice weighing 20-25 g were obtained from the animal house of the International Centre for Diarrheal Disease and Research, Bangladesh (ICDDR, B). The animals were housed under standard laboratory conditions (relative humidity 55-60\%, room temperature 23 $\pm 2^{\circ} \mathrm{C}$ and $12 \mathrm{~h}$ light: dark cycle). During the entire period of study the animals were caged individually and supplied with a standard pellet diet and water ad libitum. All animal experimentations were maintained and carried out with the guidelines of Institutional Animal Ethics Committee (IAEC, Reference no IIUC/AE 03).

\subsection{Castor oil induced diarrhea}

The experiment was carried out according to the method described by Awouters et al. [5]. Mice were fasted for $18 \mathrm{hrs}$ before the test with free access to water and randomly divided into six groups' five animals in each group. Group I was treated as control (saline $2 \mathrm{ml} / \mathrm{kg}$ bw, i.p.), Group II received standard drug (loperamide, 5 $\mathrm{mg} / \mathrm{kg}$ bw, i.p.) and Group III-VI received PFPE, PFCH, PFME and PFAQ (200 mg/kg bw, i.p.). One hr later, castor oil was administered orally to these animals to induce diarrhea. The mice were then housed individually in cages lined with 
white blotting paper. The papers were changed every hour. The total number of both dry and wet feces excreted was counted every hour for a period of $4 \mathrm{~h}$ and compared with the control group. The total number of diarrheal feces of the control group was considered $100 \%$. A numerical score based on stool consistency was assigned as follows: normal stool $=1$, semisolid stool $=2$ and watery stool $=3$. Percent inhibition $(\mathrm{PI})$ was calculated as follows:

$\mathrm{PI}=$

Mean defecation (control group-treated group) X 100

Mean defecation of control

\subsection{Castor oil induced enteropooling}

Intraluminal fluid accumulation was determined by the method of Robert et al. [6]. $18 \mathrm{hrs}$ fasted mice were divided into six groups five animals in each group. Group I served as control (saline $2 \mathrm{ml} / \mathrm{kg}$ bw, i.p.), Group II received standard drug (loperamide $5 \mathrm{mg} / \mathrm{kg}$ bw i.p.) and Group III-VI received PFPE, PFCH, PFME and PFAQ (200 mg/kg bw, i.p.). After one $\mathrm{hr}$, castor oil was administered orally to these animals to induce diarrhea. Two hrs later, the mice were sacrificed by overdose 100-120 $\mathrm{mg} / \mathrm{kg}$ of chloroform anesthesia, and the small intestine was ligated both at the pyloric sphincter and at the ileocecal junctions and dissected out. The small intestine was weighed. The intestinal contents were collected by milking into a graduated tube and the volume was measured. The intestines were reweighed and the differences between full and empty intestines were calculated.

\subsection{Castor oil induced gastrointestinal motility}

This experiment was carried out by the method described by Mascolo et al. [7]. Mice were fasted for $18 \mathrm{hrs}$ and divided into six groups of five animals each group. Castor oil was administered orally to these animals to induce diarrhea. One hour later, Group I received saline $2 \mathrm{ml} / \mathrm{kg}$ bw, i.p. Group II received standard drug (loperamide $5 \mathrm{mg} / \mathrm{kg}$ bw, i.p.) and Group III-VI received PFPE, PFCH, PFME and PFAQ (200 mg/kg bw, i.p.). After one hour, all treated animals received $1 \mathrm{ml}$ of charcoal meal (10\% charcoal suspension in $5 \%$ gum acacia) orally. In the next hour, the animals were sacrificed by overdose $100-120 \mathrm{mg} / \mathrm{kg}$ of chloroform anesthesia and the distance traveled by the charcoal meal from pylorus to caecum was measured and expressed as a percentage of the total distance of the intestine.

\subsection{Acute Toxicity Test}

Wistar albino mice maintained under standard laboratory condition were used for acute toxicity study. A total of five animals received a single oral dose $(0.5,1.0,1.5$, and $2.0 \mathrm{~g} / \mathrm{kg} \mathrm{BW})$ of the extract. Animals were kept over-night fasting prior to administration. After administration of the extract, food was withheld for further 3 to $4 \mathrm{~h}$. Animals were observed individually once during the first $30 \mathrm{~min}$ after dosing, periodically during the first $24 \mathrm{~h}$ (with special attention during the first $4 \mathrm{~h}$ ) and daily thereafter for a period of 14 days for delayed toxicity. Once daily cage side observation including changes in skin and fur, eyes and mucous membrane, respiratory and circulatory rate, autonomic and CNS changes were observed [8]. The effective therapeutic dose was taken 200 $\mathrm{mg} / \mathrm{kg} \mathrm{BW}$ as one tenth of the median lethal dose $(\mathrm{LD} 50>2.0 \mathrm{~g} / \mathrm{kg})[9]$.

\subsection{Brine shrimp lethality assay for cytotoxicity}

Brine shrimp lethality bioassay was used to determine the cytotoxic potential of the fractions of the extract $[10,11]$. Brine shrimp (Artemia salina) eggs were collected from local aquarium shop (Dhaka, Bangladesh) and hatched in artificial seawater $(3.8 \% \mathrm{NaCl}$ solution) for $48 \mathrm{hr}$ to have the grown-up shrimps called nauplii at $37^{\circ} \mathrm{C}$ temperature with continuous oxygen supply. Stock solutions of the sample were prepared by dissolving required amount of plant material in specific volume of dimethyl sulfoxide (DMSO). Four ml of seawater was given to each of the vials. Then specific volume of sample was transferred from the stock solution to the vials to attain the concentrations of 50, 100, 300, 500, $800 \mu \mathrm{g} / \mathrm{ml}$. A vial containing same volume of DMSO (as in the sample vials) was used as a 
control. Vincristine sulfate (Merck, Germany) was used as positive control. With the help of a Pasteur pipette 20 living nauplii were put into the vials. After $24 \mathrm{hr}$ the vials were observed and the number of living nauplii in each vial was counted. The percentage of mortality of Brine Shrimp nauplii was calculated for each concentration of the extract.

\section{Statistical analysis}

All results are shown as average \pm SEM. Data were statistically analyzed by one-way analysis of variance (ANOVA) followed by post hoc Dunnett's test using Statistical Package for Social Science (SPSS software, Version 18.0, IBM Corporation, NY). Values with $\mathrm{p}<0.05$ were considered as statistically significant.

\section{Results}

\subsection{Castor oil induced diarrhea}

Diarrhea appeared in all control animals after 1 hour of castor oil administration. Significant $(p<0.05)$ inhibition of diarrheal effects was produced by the ingestion of four different fractions of $P$. foetidus extract. The fractions PFPE and PFAQ showed the maximum inhibitions $78.92 \%$ and $81.61 \%$ at the dose of 200 $\mathrm{mg} / \mathrm{kg}$. These inhibitions were even higher than those of the reference antidiarrheal agent loperamide $(5 \mathrm{mg} / \mathrm{kg})$. A moderate but significant inhibition was as well achieved by another fraction PFCH, while PFME showed no significant antidiarrheal effect (Table 1).

Table 1 Effect of four different fractions of P. foetidus extract on castor oil induced diarrhea in mice.

\begin{tabular}{|c|c|c|c|c|c|c|}
\hline $\begin{array}{c}\text { Grou } \\
\mathrm{p}\end{array}$ & Treatment & Dose & $\begin{array}{c}\text { Total } \\
\text { number of } \\
\text { feces }\end{array}$ & $\begin{array}{c}\% \\
\text { inhibition } \\
\text { of } \\
\text { defecation }\end{array}$ & $\begin{array}{c}\text { Total number } \\
\text { of diarrheal } \\
\text { feces }\end{array}$ & $\begin{array}{c}\% \\
\text { inhibition } \\
\text { of } \\
\text { diarrhea }\end{array}$ \\
\hline I & Castor oil + Saline & $2 \mathrm{ml} / \mathrm{kg}$ & $15.66 \pm 0.88$ & - & $12.67 \pm 1.20$ & - \\
\hline II & Castor oil + LPM & $5 \mathrm{mg} / \mathrm{kg}$ & $7.76 \pm 1.15^{\mathrm{a}}$ & $50.44^{\mathrm{a}}$ & $5.00 \pm 0.58^{\mathrm{a}}$ & $60.53^{\mathrm{a}}$ \\
\hline III & Castor oil + PFME & $200 \mathrm{mg} / \mathrm{kg}$ & $9.67 \pm 0.29^{\mathrm{a}}$ & $38.25^{\mathrm{a}}$ & $6.00 \pm 0.5^{\mathrm{a}}$ & $52.64^{\mathrm{a}}$ \\
\hline IV & Castor oil + PFPE & $200 \mathrm{mg} / \mathrm{kg}$ & $5.00 \pm 1.00^{\mathrm{b}}$ & $68.07^{\mathrm{b}}$ & $2.67 \pm 1.25^{\mathrm{b}}$ & $78.92^{\mathrm{b}}$ \\
\hline V & Castor oil + PFCH & $200 \mathrm{mg} / \mathrm{kg}$ & $8.00 \pm 1.00^{\mathrm{c}}$ & $48.91^{\mathrm{c}}$ & $5.00 \pm 0.52^{\mathrm{c}}$ & $60.54^{\mathrm{c}}$ \\
\hline VI & Castor oil + PFAQ & $200 \mathrm{mg} / \mathrm{kg}$ & $3.50 \pm 1.25^{\mathrm{d}}$ & $77.65^{\mathrm{d}}$ & $2.33 \pm 1.04^{\mathrm{d}}$ & $81.61^{\mathrm{d}}$ \\
\hline
\end{tabular}

$\mathrm{LPM}=$ Loperamide, $\mathrm{PFME}=$ methanol fraction, $\mathrm{PFPE}=$ petroleum ether fraction, $\mathrm{PFCH}=$ chloroform fraction, $\mathrm{PFAQ}=$ aqueous fraction. Data are shown as Mean \pm SEM of five animals in each group. Values with superscript letters $^{\mathrm{a}-\mathrm{d}}$ are significantly $(p<0.05)$ different from each other. Data were analyzed by one-way ANOVA followed by Tukey's post hoc test (SPSS, Version 18.0) for multiple comparisons.

\subsection{Castor oil induced enteropooling}

Castor oil caused accumulation of water and electrolytes in intestinal loop. Administration of $200 \mathrm{mg} / \mathrm{kg}$ of PFPE, PFCH, PFME and PFAQ fractions produced a significant $(p<0.05)$ reduction compared to the reference antidiarrheal agent loperamide $(5 \mathrm{mg} / \mathrm{kg})$ in intestinal weight and volume (Table 2). Antidiarrheal effects of all 
the fractions were close to each other in castor oil induced enteropooling method.

\subsection{Castor oil induced gastrointestinal motility}

Pandanus foetidus extract reduced the gastrointestinal distance travelled by the charcoal meal in animals at the dose of 200 $\mathrm{mg} / \mathrm{kg}$. Among the four fractions, PFAQ produced the highest reduction $(43.49 \%)$ of gastrointestinal motility which was significant $(\mathrm{p}$ $<0.05)$ compared to positive control loperamide $(5 \mathrm{mg} / \mathrm{kg})$ producing a marked decrease in the propulsion of charcoal meal through gastrointestinal tract (Table 3).

Table 2 Effect of four different fractions of $P$. foetidus extract on castor oil induced enteropooling in mice.

\begin{tabular}{|c|c|c|c|c|c|}
\hline $\begin{array}{l}\text { Grou } \\
\mathrm{p}\end{array}$ & Treatment & Dose & $\begin{array}{l}\text { Volume of } \\
\text { intestinal } \\
\text { content }(\mathrm{ml})\end{array}$ & $\begin{array}{l}\text { Weight of } \\
\text { intestinal } \\
\text { content }(\mathrm{g})\end{array}$ & $\begin{array}{c}\% \text { Inhibition } \\
\text { of intestinal } \\
\text { content }\end{array}$ \\
\hline I & $\begin{array}{c}\text { Castor oil + } \\
\text { Saline }\end{array}$ & $2 \mathrm{ml} / \mathrm{kg}$ & $0.67 \pm 0.04$ & $1.76 \pm 0.03$ & \\
\hline II & $\begin{array}{c}\text { Castor oil + } \\
\text { LPM }\end{array}$ & $5 \mathrm{mg} / \mathrm{kg}$ & $0.48 \pm 0.04^{\mathrm{a}}$ & $1.18 \pm 0.04^{\mathrm{a}}$ & $32.95^{\mathrm{a}}$ \\
\hline III & $\begin{array}{l}\text { Castor oil + } \\
\text { PFME }\end{array}$ & $200 \mathrm{mg} / \mathrm{kg}$ & $0.30 \pm 0.05^{\mathrm{b}}$ & $0.68 \pm 0.08^{b}$ & $61.36^{\mathrm{b}}$ \\
\hline IV & $\begin{array}{l}\text { Castor oil + } \\
\text { PFPE }\end{array}$ & $200 \mathrm{mg} / \mathrm{kg}$ & $0.4 \pm 0.05^{\mathrm{c}}$ & $0.85 \pm 0.09^{c}$ & $51.70^{\mathrm{c}}$ \\
\hline V & $\begin{array}{c}\text { Castor oil + } \\
\text { PFCH }\end{array}$ & $200 \mathrm{mg} / \mathrm{kg}$ & $0.35 \pm 0.02^{\mathrm{d}}$ & $0.67 \pm 0.05^{\mathrm{d}}$ & $61.93^{\mathrm{d}}$ \\
\hline VI & $\begin{array}{c}\text { Castor oil + } \\
\text { PFAQ }\end{array}$ & $200 \mathrm{mg} / \mathrm{kg}$ & $0.37 \pm 0.03^{\mathrm{a}}$ & $0.76 \pm 0.02^{\mathrm{a}}$ & $56.8^{\mathrm{a}}$ \\
\hline
\end{tabular}

LPM=Loperamide, $\mathrm{PFME}=$ methanol extract, $\mathrm{PFPE}=$ petroleum ether extract, $\mathrm{PFCH}=$ chloroform extract, $\mathrm{PFAQ}=$ aqueous extract. Data are shown as Mean \pm SEM of five animals in each group. Values with superscript letters $^{\mathrm{a}-\mathrm{d}}$ are significantly $(p<0.05)$ different from each other. Data were analyzed by one-way ANOVA followed by Tukey's post hoc test (SPSS, Version, 18) for multiple comparisons.

\subsection{Brine shrimp lethality assay for cytotoxicity}

In brine shrimp lethality bioassay, the tested fractions showed a concentration dependent mortality of freshly hatched nauplii. All the fractions except PFCH (at $500 \mu \mathrm{g} / \mathrm{ml}$ ) achieved $100 \%$ mortality at the concentration of 800 $\mu \mathrm{g} / \mathrm{mL}$ (Figure 1) . PFCH was found to be the most toxic to observe the order of toxicity as $\mathrm{PFCH}>\mathrm{PFME}>\mathrm{PFAQ}>\mathrm{PFPE}$, indicating that
$\mathrm{PFCH}$ possessed the lowest $\mathrm{LC}_{50}$ value, 106.97 $\mu \mathrm{g} / \mathrm{ml}$ (Table 4).

\section{Discussion}

Different fractions of $P$. foetidus leaf extract was evaluated for antidiarrheal effect in castor oil induced intestinal motility, intraluminal fluid accumulation as well as frequency of defecation. Usually diarrhea is considered as a consequence of altered motility 
and fluid accumulation in intestinal tract. Diarrhea can be induced by castor oil through the production of active metabolite ricinolic acid [12]. Ricinolic acid increases peristaltic activity and produces permeability changes in the intestinal mucosal membrane to electrolytes and water. More precisely, castor oil elevates the biosynthesis of prostaglandin $[5,13,14]$ which results in irritation and inflammation of the intestinal mucosa to stimulate the motility and secretion [14-16]. Castor oil model, therefore, incorporates both secretory and motility diarrhea [17].

Table 3 Effect of four different fractions of $P$. foetidus extract on charcoal induced gut transit changes in mice.

\begin{tabular}{|c|c|c|c|c|c|}
\hline Group & Treatment & Dose & $\begin{array}{l}\text { Total } \\
\text { length of } \\
\text { intestine } \\
(\mathrm{cm})\end{array}$ & $\begin{array}{c}\text { Distance } \\
\text { traveled by } \\
\text { marker }(\mathrm{cm})\end{array}$ & $\begin{array}{c}\% \text { of } \\
\text { inhibition }\end{array}$ \\
\hline $\mathrm{I}$ & $\begin{array}{c}\text { Castor oil + } \\
\text { Saline }\end{array}$ & $2 \mathrm{ml} / \mathrm{kg}$ & $59.60 \pm 0.83$ & $\begin{array}{c}54.43 \pm \\
0.87\end{array}$ & - \\
\hline II & $\begin{array}{c}\text { Castor oil + } \\
\text { LPM }\end{array}$ & $5 \mathrm{mg} / \mathrm{kg}$ & $60.60 \pm 1.13$ & $\begin{array}{c}32.37 \pm \\
2.15^{\mathrm{a}}\end{array}$ & 40.52 \\
\hline III & Castor oil + PFME & $200 \mathrm{mg} / \mathrm{kg}$ & $52.60 \pm 2.20$ & $\begin{array}{c}40.30 \pm \\
1.00^{\mathrm{a}}\end{array}$ & 25.96 \\
\hline IV & Castor oil + PFPE & $200 \mathrm{mg} / \mathrm{kg}$ & $57.00 \pm 1.52$ & $\begin{array}{c}43.65 \pm \\
0.83^{\mathrm{a}}\end{array}$ & 19.81 \\
\hline V & Castor oil + PFCH & $200 \mathrm{mg} / \mathrm{kg}$ & $55.00 \pm 2.50$ & $\begin{array}{c}35.45 \pm \\
5.60^{\mathrm{b}}\end{array}$ & 34.87 \\
\hline VI & Castor oil + PFAQ & $200 \mathrm{mg} / \mathrm{kg}$ & $51.00 \pm 0.80$ & $\begin{array}{c}30.76 \pm \\
0.37^{\mathrm{c}}\end{array}$ & 43.49 \\
\hline
\end{tabular}

$\mathrm{LPM}=$ Loperamide, $\mathrm{PFME}=$ methanol extract, $\mathrm{PFPE}=$ petroleum ether extract, $\mathrm{PFCH}=$ chloroform extract, $\mathrm{PFAQ}=$ aqueous extract. Data are shown as Mean \pm SEM of five animals in each group. Values with superscript letters $^{\mathrm{a}-\mathrm{c}}$ are significantly $(p<0.05)$ different from each other. Data were analyzed by one-way ANOVA followed by Tukey's post hoc test (SPSS, Version 18.0) for multiple comparisons.

Table 4 Cytotoxic potential of four different fractions of $P$. foetidus leaves.

\begin{tabular}{llll} 
Extracts & Regression Line & $\begin{array}{l}\text { Regression } \\
\text { coefficient }\end{array}$ & $\mathbf{L C}_{\mathbf{5 0}}(\boldsymbol{\mu} \mathbf{g} / \mathbf{m l})$ \\
\hline PFME & $\mathrm{Y}=66.138 \mathrm{X}-102.82$ & $\mathrm{R}^{2}=0.9125$ & $242.83 \pm 1.97$ \\
PFPE & $\mathrm{Y}=15.709 \mathrm{X}-12.009$ & $\mathrm{R}^{2}=0.9739$ & $4842.87 \pm 2.11$ \\
PFCH & $\mathrm{Y}=65.388 \mathrm{X}-83.055$ & $\mathrm{R}^{2}=0.9766$ & $106.97 \pm 1.56$ \\
PFAQ & $\mathrm{Y}=51.159 \mathrm{X}-76.532$, & $\mathrm{R}^{2}=0.6193$ & $1320.45 \pm 2.05$ \\
VS & $\mathrm{Y}=52.692 \mathrm{X}-51.542$ & $\mathrm{R}^{2}=0.9979$ & $0.76 \pm 0.04 \mathrm{lg} / \mathrm{ml}$ \\
\hline
\end{tabular}

$\mathrm{PFME}=$ methanol extract, $\mathrm{PFPE}=$ petroleum ether extract, $\mathrm{PFCH}=$ chloroform extract, $\mathrm{PFAQ}=$ aqueous extract, $\mathrm{VS}=$ Vincristine sulfate. Data are shown as Mean \pm SEM of five animals in each group. 


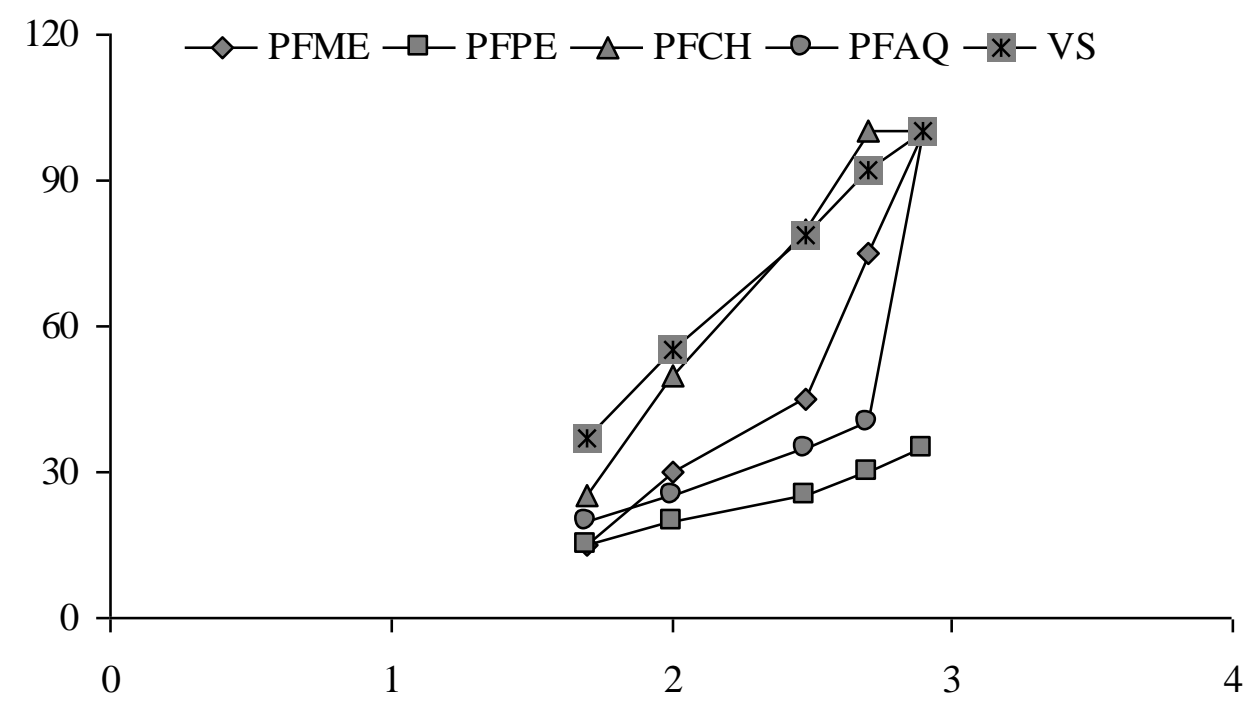

Figure 1 Mortality of the Brine shrimps by the treatment of PFME= methanol extract, PFPE= petroleum ether extract, $\mathrm{PFCH}=$ chloroform extract, $\mathrm{PFAQ}=$ aqueous extract, $\mathrm{VS}=\mathrm{Vincristine}$ sulfate (standard cytotoxic agent).

The use of plant-derived medicines for the treatment of diarrhea is a common practice in many folk medications. Many people in the developing countries still rely on the treatment system employing medicinal plants [18]. Relevantly, different fractions of $P$. foetidus leaf used in our study were found to be significantly antidiarrheal in castor oil induced changes of gastrointestinal tract. However, PFAQ and PFPE of the extract displayed the highest inhibitory action in the antidiarrheal models. The abovementioned function needs to be clarified with the possible mechanism how the extract works for exerted effects so that the plant species can be used for antidiarrheal formulation.

As we discussed the central role of prostaglandin to cause diarrhea, several other mechanisms had been previously proposed to explain the diarrheal effect of castor oil which include inhibition of intestinal $\mathrm{Na}+\mathrm{K}+$ ATPase activity, thus reducing normal fluid absorption [17]. It is possible that the $P$. foetidus fractions were able to inhibit electrolyte permeability due to castor oil and prostaglandins release [19]. Suppression of the intestinal fluid accumulation by the extract might also suggest the inhibition of gastrointestinal function [20]. The above speculation was further supported by the inhibitory action of the extract on intestinal charcoal meal motility. However, it is well proved that castor oil produces diarrhea due to its most active component ricinoleic acid through a hypersecretory response [ 12, 15]. Therefore, it can be assumed that the antidiarrheal action of the extract was mediated by an antisecretory mechanism and also by reducing gastrointestinal motility contributed by the phytochemical agents possessed by the plant extract.

Phytochemical screening of the ethanolic extract of $P$. foetidus ensured the presence of carbohydrate, glycoside, alkaloids, tannins, flavonoids and steroids [21]. The inhibitory activity of flavonoids on intestinal motility in a dose related manner was earlier reported [22, 23]. Apart from this, previous studies have shown that antidysenteric and antidiarrheal properties of plants are due to tannins, alkaloids, saponins, flavonoids, sterol, triterpenes and reducing sugars [24]. These findings are consistent with the phytochemical existence of $P$. foetidus. Therefore, the antidiarrheal activity of the ethanolic extract of P. foetidus may be attributed to the phytochemicals present in this plant and it is as well supported by literature for other plants $[25,26]$.

Toxic effect of plant-derived substances is a major concern to scientists and medical 
practitioners [27]. Therefore, cytotoxic assay was conducted in this study to determine the toxicity profile of the plant extracts through the Brine shrimp lethality $\left(\mathrm{LC}_{50}, 24 \mathrm{~h}\right)$ test. It is reported that $\mathrm{LC}_{50}$ value higher than $1000 \mu \mathrm{g} / \mathrm{ml}$ is considered as a cutoff point for a plant material to be non-toxic and the value less than $1000 \mu \mathrm{g} / \mathrm{ml}$ is detected as potentially harmful in brine shrimp sensitivity test. According to the observation, the PFPE and PFAQ fractions of $P$. foetidus were found nontoxic to be used as antidiarrheal agents. However, the two other fractions $\left(\mathrm{LC}_{50}<1000\right.$ $\mu \mathrm{g} / \mathrm{ml})$, detected as toxic, were also important for pharmaceutical formulation against tumor cells, pesticides etc. as the brine shrimp cytotoxicity assay is considered as a convenient probe for preliminary assessment of toxicity, detection of fungal toxins, pesticidal and anti-tumor effect [10, $28,29]$.

\section{Conclusion}

This study supports the PFPE and PFAQ fractions of $P$. foetidus leaf are the prospective sources of antidiarrheal agent in the traditional medicine system. However, further studies are required to identify the active constituent(s) of the fractions to understand the pharmacological action of the antidiarrheal and cytotoxic effects.

\section{Acknowledgement}

Authors wish to thank Dr. Sheikh Bokhtear Uddin, Associate professor, Department of Botany, University of Chittagong for the taxonomical identification the plant. The authors are also grateful to the authority of International Centre for Diarrheal Disease and Research, Bangladesh (ICDDR, B) for providing the experimental mice and to International Islamic University Chittagong, Chittagong, Bangladesh for providing research facilities.

\section{Conflict of interest statement}

The authors declare that they have no conflict of interest.

\section{References}

1 Chaffey, D.R.; Sandom, J.H.; Sunderbans forest inventory project, Bangladesh. A glossary of vernacular plant names and a field key to Trees. Overseas Development Administration England, 1985, pp 46.

2 Joshi, S.G. Medicinal Plants. Oxford and IBH Publishing Co. Ltd, India, 2000.

3 Yusuf, M.; Chowdhury, J.U.; Wahab, M.A.; Begum, J. Medicinal plants of Bangladesh, BCSIR Laboratories, Bangladesh, 1994, pp 66-217.

4 Uddin, S.J.; Shilpi, J.A.; Delazar, A.; Nahar, L.; Sarker, S.D. Free radical scavenging activity of some Bangladeshi plant extracts, Orient Pharm Experim Med, 2005, 4, 185193.

5 Awouters, F.; Niemegeers, C.J.E.; Lenaerts, F.M.; Janseen, P.A.J. Delay of castor oil diarrhea in rats; a new way to evaluate inhibitors of prostaglandin biosynthesis, $J$ Pharmacol, 1998, 30, 41-5. DOI: 10.1111/j.2042-7158.1978.tb13150.x

6 Robert, A.; Nezamis, J.E.; Lancaster, C.; Hanchar, A.J.; Klepper, M.S. Enteropooling assay; a test for diarrhea produced by prostaglandins, Prostaglandins, 1976, 11, 809-28. DOI: 10.1016/00906980(76)90189-1

7 Mascolo, N.; Izzo, A.A.; Autore, G.; Barbato, F.; Capasso, F. Nitric oxide and castor oil- induced diarrhea, J Pharmacol Exp Ther, 1994, 268, 291-5. DOI:10.1016/1043-6618(94)80070-7

8 Zaoui, A.; Cherrah, Y.; Mahassini, N.; Alaoui, K.; Amarouch, H.; Hassar, M. Acute and chronic toxicity of Nigella sativa fixed oil. Phytomedicine 2002, 9, 69-74. Doi:10.1078/0944-7113-00084

9 Handa, S.S.; Sharma, A. Hepatoprotective activity of andrographolide from Andrographies paniculata against carbontetrachloride. Indian J Med Res 1990, 92, 276-283.

10 Meyer, B.N.; Ferrigni, N.R.; Putnam, J.E.; Jacobsen, J.B.; Nichols, D.E.; Mclaughlin, J.L. Brine shrimp; a convenient general 
bioassay for activeplant constituents. Planta Medica, 1982, 45, 31-34.

11 Persoone, G. Proceeding of the international symposium on brine shrimp; Artemia salina; University press, Belgium, 1988.1-3.

12 Ammon, H.V.; Thomas, P.J.; Phillips, S.F. Effect of the oleic acid and ricinoleic acid net jejunal water and electrolyte movement, J Clin Invest, 1974, 53, 374-9. Doi: 10.1172/JCI107569.

13 Bruton, L.L. Agents affecting gastrointestinal water flux and motility digestant: and bile acids. In: A.G. Gillman, T.W. Rail, A.S. Nies and P. Taylor, Editors, Pharmacol. Basis of Therapeutics, 8th ed, vol.2, McGraw, New York, 1985. 914.

14 Galvez, J.; Zarzuelo, A.; Crespo, M.E. Antidiarrhoeic activity of Scleroarya birrea bark extract and its active tannin constituent in rats, Phytother Res, 1991, 5, 276-278.

15 Gaginella, T.S.; Bass, P. Laxatives: an update on mechanism of action. Life Sci, 1978, 23, 1001-10.

16 Pierce, N.F.; Carpenter, C.C.J.; Elliot, H.Z.; Greenough, W.B. Effects of prostaglandins, theophylline and cholera exotoxin upon transmucosal water and electrolyte movement in canine jejunum, Gastroenterol, 1971, 60, 22-32.

17 Yegnanarayan, R.; Shrotri, M.D.D.S. Comparison of antidiarrhoeal activity of some drugs in experimental diarrhea, Indian $J$ Pharmacol, 1982, 14, 293-299.

18 Ojewole, J.A.O. Evaluation of antidiarrheal, anti-inflammatory and antidiabetic properties of Sclerocarya birrea (A. Rich.) Hochst. stem bark aqueous extract in mice and rats, Phytotherapy Res, 2004,18, 601-608.

19 Adzu, B.; Amos, S.; Wambebe, C.; Gamaniel, K. Antinociceptive activity of Ziziphus spinachristi root bark extract, Fitoterapia, 2001, 72, 334-350. DOI:10.1016/S0367326X(00)00289-6.

20 Nwafor, P.A.; Okwuasaba, F.K.; Binda, L.G. Antidiarrhoeal and antiulcerogenic effects of methanolic extract of Asparagus pubescent root in rats, J Ethnopharmacol, 2000, 72, 421-427.DOI:10.1016/S0378-8741(00)00261-0.
21 Hossain, M.L.; Hossain, M.A.A.S.M; Sarkar, K.K.; Hossain, A.; Rahman M.A. Phytochemical screening and the evaluation of the antioxidant, total phenolic content and analgesic properties of the plant Pandanus foetidus (family pandanaceae). Int Res J Pharmacy, 2013, 4, 170-172.

22 Dicarlo, G.D.; Mascolo, N.; Izzo, A.A.; Capasso, F. Effect of querecetine on the gastrointestinal tract in rats and mice. Phytother Res 1994, 8, 42-45. DOI: $10.1002 /$ ptr.2650080110.

23 Meli, R.; Autore, G.; Dicarlo, G.; Capasso, F. Inhibitory action of querecetin on intestinal transit in mice. Phytother Res 1990, 4, 201202. DOI: $10.1002 /$ ptr.2650040509.

24 Longanga, O.A.; Vercruysse, A.; Foriers, A. Contribution to the ethnobotanical, phytochemical and pharmacological studies of traditionally used medicinal plants in the treatment of dysentery and diarrhoea in Lomela area, Democratic Republic of Congo (DRC). J Ethnopharmacol 2000, 71, 411423. DOI: 10.1016/S0378-8741(00)00167-7.

25 Dahiru, D.; Sini, J.M.; John-Africa, L. Antidiarrhoeal activity of Ziziphus mauritiana root extract in rodents. Afr J Biotechnol 2006, 5, 941-945.

26 Boominathan, P.; Shukla, R.; Kumar, A.; Manna, D.; Negi, D.; Verma, P.K.; Chattopadhyay, D. Long term transcript accumulation during the development of dehydration adaptation in Cicer arietinum. Plant Physiology 2004, 135,1608-1620.

27 Rahman, M.A.; Sultana, R.; Emran, T.B.; Islam, M.S.; Rahman, M.A.; Chakma, J.S.; Rashid, H.U.; Hasan C. M. M. Effects of organic extracts of six Bangladeshi plants on in vitro thrombolysis and cytotoxicity, BMC Complement Altern Med, 2013, 13:25. Doi:10.1186/1472-6882-13-25.

28 McLaughlin, J.L.; Anderson, J.E.; Chang CJ. Bioactive components of Allamanda schottii, J Nat Prod, 1988, 51, 307-8. DOI: 10.1021/np50056a018.

29 Shirazi, F.H.; Ahmadi, N.; Kamalinejad, M. Evaluation of Northern Iran Mentha pulegium L. cytotoxicity, Daru, 2004,12, 106-110. 